\title{
Tomasz Węgrzyn
}

Uniwersytet Ekonomiczny w Katowicach

\section{WERYFIKACJA ZASTOSOWANIA METODY PORZĄDKOWANIA LINIOWEGO HELLWIGA W KONTEKŚCIE DOBORU SPÓLEK DO PORTFELA. ANALIZA W LATACH 2001-2010}

\begin{abstract}
Streszczenie: Celem artykułu jest ocena, czy w kontekście doboru do portfela spółki powinny być oceniane na podstawie dynamiki wskaźników finansowych czy na podstawie zarówno wartości nominalnych wskaźników finansowych, jak i ich dynamik. Portfele są oceniane na podstawie wyników inwestycyjnych. Spółki są dobierane do portfeli kwantylowych na podstawie pozycji w rankingu konstruowanym na podstawie wybranych wskaźników finansowych (wartości nominalnych lub/oraz ich dynamik). W rezultacie przeprowadzonych badań można stwierdzić, że najlepsze dwa portfele zostały wskazane na podstawie rankingu skonstruowanego z wykorzystaniem wartości nominalnych wskaźników finansowych oraz ich dynamik.
\end{abstract}

Słowa kluczowe: wskaźniki finansowe, konstrukcja portfela, syntetyczny miernik rozwoju.

DOI: $10.15611 /$ nof.2014.1.08

\section{Wstęp}

Inwestorzy operujący na dzisiejszych rynkach finansowych, które coraz częściej przybierają wirtualny charakter, dzięki dostępowi do nich przez platformy elektroniczne, muszą analizować setki przedsiębiorstw. Wykorzystanie statystycznych metod porządkowania liniowego do oceny atrakcyjności inwestycyjnej spółek giełdowych pozwala znacząco skrócić czas niezbędny do przeprowadzenia tej analizy. Jednakże jakość przeprowadzonej oceny przedsiębiorstw zależy w głównej mierze od doboru wskaźników finansowych. Model TMAI [Tarczyński 1994, s. 275-300], zaproponowany przez Tarczyńskiego, wykorzystuje metodę Hellwiga [1968, s. 307-324] i pozwala na ocenę atrakcyjności spółek oraz na ich liniowe uporządkowanie.

Tarczyński i Łuniewska w ocenie przedsiębiorstw stosują wskaźniki opisujące cztery podstawowe obszary działalności przedsiębiorstwa, tj. rentowność, płynność, sprawność zarządzania, zadłużenie [Tarczyński, Łuniewska 2003]. Węgrzyn zaproponował rozszerzenie analizy o dynamikę wskaźników finansowych mierzoną przez 
względne tempo przyrostu [Węgrzyn 2007]. Badania prowadzone przez Tarczyńskiego i Łuniewską (por. [Łuniewska 2003a; Łuniewska 2003b; Tarczyński, Łuniewska 2004]) oraz przez Węgrzyna (por. [2007; 2013b, s. 356-361; 2013c, s. 1554-1564]) jednoznacznie wskazują na możliwość stosowania syntetycznego miernika rozwoju do oceny spółek w kontekście ich doboru do portfela. Węgrzyn wskazuje, że w przypadku konstrukcji portfeli kwantylowych ze względu na nominalne wartości wskaźników finansowych oraz ich dynamikę w długim okresie najlepsze rezultaty daje inwestycja w portfel drugi [Węgrzyn 2013a]. Należy zauważyć, że etap doboru spółek do portfela dotyczy inwestorów, którzy nie zamierzają zajmować pozycji w portfelu rynkowym, np. ze względu na wielkość posiadanego kapitału. Ponadto sam dobór spółek do portfela jest etapem wstępnym, a kolejnym jest optymalizacja jego struktury, która może zostać przeprowadzona z wykorzystaniem klasycznego podejścia Markowitza [1952].

Celem artykułu jest próba odpowiedzi na pytanie, czy w kontekście doboru do portfela spółki powinny być oceniane jedynie na podstawie dynamiki wskaźników finansowych czy też konieczna jest ich ocena na podstawie zarówno wartości nominalnych wskaźników finansowych, jak i ich dynamik. W celu odpowiedzi na postawione pytanie analizowane są wyniki inwestycyjne portfeli kwantylowych konstruowanych na podstawie dwóch grup zmiennych opisujących spółki. Pierwsza grupa zmiennych obejmuje dynamiki wskaźników finansowych. Druga grupa zmiennych obejmuje wartości nominalne wskaźników finansowych oraz ich dynamiki. Spółki dobierane są do portfeli na podstawie pozycji w rankingu, który jest budowany na podstawie wartości syntetycznego miernika rozwoju oddzielnie na podstawie pierwszej oraz drugiej grupy zmiennych.

Do oceny zbudowanych proporcjonalnych portfeli wykorzystane są: stopa zwrotu, odchylenie standardowe stopy zwrotu oraz wskaźnik Sharpe'a [1966, s. 119]. Ponadto zbudowane portfele oceniane są na tle dobrze zdywersyfikowanego portfela proporcjonalnego zawierającego wszystkie analizowane w danym roku spółki.

\section{Względne tempo przyrostu}

Duża liczba wskaźników finansowych może przyjmować wartości zarówno dodatnie, jak i ujemne. Dlatego względne tempo przyrostu zdefiniowano w następujący sposób [Węgrzyn 2007; 2013a; 2013c]:

$$
\delta=\frac{\Delta W_{t_{1}}}{\left|W_{t_{0}}\right|}=\left\{\begin{array}{ll}
\frac{W_{t_{1}}-\left|W_{t_{0}}\right|}{\left|W_{t_{0}}\right|} & \text { gdy } W_{t_{1}}<0 \wedge W_{t_{0}}<0 \\
\frac{W_{t_{1}}-W_{t_{0}}}{\left|W_{t_{0}}\right|} & \text { gdy } W_{t_{0}} \neq 0
\end{array},\right.
$$


gdzie: $W_{t 1}$ - wartość wskaźnika w roku bieżącym,

$W_{t 0}$ - wartość wskaźnika w roku poprzednim.

Wartości uzyskanych przy wykorzystaniu wzoru (1) nie można jednoznacznie zinterpretować. Taka możliwość istnieje tylko, gdy obie porównywane wielkości ( $W_{t_{0}}$ oraz $W_{t_{1}}$ ) przyjmują wartości dodatnie. Ponadto w przypadku, gdy $W_{t_{0}}$ przyjmuje wartość równą zeru, względnego tempa przyrostu nie można wyznaczyć. Proponowana metoda ma zastosowanie, gdy wśród danych wejściowych do porządkowania liniowego znajdują się wielkości ujemne (np. straty) oraz dodatnie (np. zyski) i jednocześnie:

- pozytywnie oceniane jest zwiększenie zysków (wielkości dodatnich),

- negatywnie oceniane jest zmniejszenie zysków (wielkości dodatnich),

- pozytywnie oceniane jest pojawienie się zysku (wielkości dodatniej) w miejsce straty (wielkości ujemnej),

- negatywnie oceniane jest pojawienie się straty (wielkości ujemnej) w miejsce zysku (wielkości dodatniej),

- negatywnie oceniane jest zarówno zwiększenie oraz zmniejszenie strat (wielkości ujemnych).

\section{Wybrane wskaźniki finansowe w ocenie spółek niefinansowych}

Wykorzystując pracę Ritchiego [1997], postanowiono do konstrukcji syntetycznego miernika rozwoju (wskaźnika TMAI) zastosować wartości nominalne oraz względne tempa przyrostu następujących wskaźników finansowych ${ }^{1}$ :

\section{A. wskaźniki rentowności:}

- rentowność kapitału własnego ROE* [Bednarski, Waśniewski 1996, s. 480; Jerzemowska 2006, s. 293],

- rentowność aktywów ROA* [Bednarski, Waśniewski 1996, s. 472; Jerzemowska 2006, s. 292],

- rentowność sprzedaży ROS* [Bednarski, Waśniewski 1996, s. 457; Jerzemowska 2006, s. 287],

- marżę zysku brutto ze sprzedaży MZBS* [Jerzemowska 2006, s. 289],

- marżę zysku operacyjnego MZOP*2,

- marżę zysku brutto MZB* [Helfert 2003, s. 149],

- przychody ze sprzedaży,

- zysk operacyjny,

- zysk netto.

1 Gwiazdką (*) zaznaczono wskaźniki, dla których wyznaczono zarówno wartość nominalną, jak i względne tempo przyrostu. Dla wskaźników nieoznaczonych gwiazdką wyznaczono jedynie względne tempa przyrostu.

${ }^{2}$ MZOP wyznaczano analogicznie do MZBS, z tym że we wskaźniku zysk ze sprzedaży zastąpiono zyskiem operacyjnym. 


\section{B. wskaźniki płynności:}

- wskaźnik płynności bieżącej WPB* [Jerzemowska 2006, s. 137; Helfert 2003, s. 178],

- wskaźnik płynności szybkiej WPS* [Jerzemowska 2006, s. 138; Helfert 2003, s. 179],

- wskaźnik podwyższonej płynności WPP* [Jerzemowska 2006, s. 138],

- wskaźnik rentowność gotówkowa sprzedaży RGS* [Waśniewski, Skoczylas 1996; 1999; Wędzki 2006, s. 513],

- wskaźnik rentowność gotówkowa zysku netto RGZ* [Waśniewski, Skoczylas 1996; 1999; 2002, s. 463],

- gotówka z działalności operacyjnej [Waśniewski, Skoczylas 1996; 1999].

\section{C. wskaźniki sprawności zarządzania:}

- wskaźnik rotacji aktywów w dniach RA* [Helfert 2003, s. 157; Ritchie 1997, s. 215],

- wskaźnik rotacji należności w dniach RNAL* [Jerzemowska 2006, s. 231],

- wskaźnik rotacji zapasów w dniach RZAP* [Jerzemowska 2006, s. 226],

- cykl operacyjny w dniach COP*3,

- wskaźnik rotacji zobowiązań w dniach RZOB* [Jerzemowska 2006, s. 235],

- wskaźnik rotacji majątku obrotowego w dniach RMO* [Jerzemowska 2006, s. 235],

- cyk1 konwersji gotówki CKG* [Jerzemowska 2006, s. 235].

\section{D. wskaźniki zadłużenia:}

- wskaźnik zadłużenia ogólnego SZO* [Bednarski, Waśniewski 1996],

- wskaźnik pokrycia majątku kapitałem własnym WPM*4,

- wskaźnik obsługi zadłużenia WOZ* [Jerzemowska 2006, s. 161],

- wskaźnik pokrycia zobowiązań WPZ*5.

\section{Przyjęte zalożenia i procedura badawcza}

Badaniem objęto spółki notowane na GPW w ciągu 10 kolejnych lat, tj. od $04.2001 \mathrm{r}$. do $04.2011 \mathrm{r}$. W badaniu uwzględniono spółki, które w końcu marca danego roku znajdowały się w portfelu jednego z następujących indeksów: WIG20, mWIG40 (midWIG), sWIG80 (WIRR). Spośród tych spółek z badania wyłączono:

- firmy z sektorów: banki, ubezpieczenia, finanse - inne,

- firmy, dla których w danym roku nie posiadano sprawozdań finansowych ${ }^{6}$ za dwa poprzednie lata,

${ }^{3}$ Cykl operacyjny definiowany jako suma wskaźników RZAP i RNAL pokazuje, ile dni upływa od momentu zakupu zapasów do płatności faktury za sprzedane towary i usługi,

${ }^{4}$ Wskaźnik wyznaczany jako iloraz kapitału własnego do aktywów trwałych.

${ }^{5}$ Wskaźnik wyznaczany jako iloraz zobowiązań do zysku operacyjnego powiększonego o amortyzację.

${ }^{6}$ Sprawozdania finansowe wykorzystane $\mathrm{w}$ badaniach pochodziły z następujących baz danych: zeszyty 1(39)/2003,3(45)/2004, wersja 18.30 maj 2010, wydanych przez Notorię Serwis. 
- firmy, które w jednym ze sprawozdań finansowych (na podstawie których wyznaczano wartości wskaźników finansowych) wykazały ujemne kapitały własne,

- firmy, które w jednym ze sprawozdań finansowych (na podstawie których wyznaczano wartości wskaźników finansowych) wykazały zerowe przychody ze sprzedaży.

W rezultacie w kolejnych latach do badań zakwalifikowano od 95 spółek w roku 2002 do 118 spółek w roku 2010. Liczbę spółek spełniających przyjęte założenia w kolejnych latach przedstawiono w tab. 1 .

Tabela 1. Liczba spółek zakwalifikowanych do badań w kolejnych latach

\begin{tabular}{|c|c|}
\hline Rok & Liczba spółek \\
\hline 2001 & 96 \\
\hline 2002 & 95 \\
\hline 2003 & 97 \\
\hline 2004 & 102 \\
\hline 2005 & 108 \\
\hline 2006 & 105 \\
\hline 2007 & 106 \\
\hline 2008 & 113 \\
\hline 2009 & 117 \\
\hline 2010 & 118 \\
\hline
\end{tabular}

Źródło: opracowanie własne.

Dla każdej ze spółek zakwalifikowanych do badania w danym roku wyznaczono wartości wskaźników finansowych oraz ich względne tempa przyrostu. $\mathrm{Na}$ ich podstawie dla każdej spółki wyznaczono dwa syntetyczne mierniki rozwoju. Jeden na podstawie względnych temp przyrostu wskaźników finansowych (TMAI_delta), drugi na podstawie wartości nominalnych wskaźników finansowych oraz ich względnych temp przyrostu (TMAI_nom_delta). W rezultacie spółki zostały uporządkowane w dwóch rankingach TMAI_delta oraz TMAI_nom_delta.

Na podstawie pozycji spółki w danym rankingu kwalifikowano ją do jednego z pięciu portfeli kwantylowych w następujący sposób:

- do pierwszego portfela trafia 20\% spółek, które znalazły się najwyżej w rankingu,

- do drugiego, trzeciego i czwartego portfela trafia po $20 \%$ spółek, znajdujących się na kolejnych pozycjach (które nie znalazły się w portfelu o wyższym numerze), - do piątego portfela trafiają pozostałe spółki z rankingu.

W rezultacie w każdym kolejnym roku powstawało pięć równolicznych portfeli dla każdego z rankingów. Struktury portfeli nie optymalizowano - budowano portfele proporcjonalne. W każdą ze spółek inwestowano 10000 zł, liczbę nabywanych akcji zaokrąglano do liczby całkowitej w dół. Liczba akcji poszczególnych spółek w okresie inwestycji była stała. Każdy z portfeli nabywano na ostatniej sesji przypa- 
dającej w pierwszym tygodniu kwietnia danego roku i sprzedawano na ostatniej sesji przypadającej w pierwszym tygodniu kwietnia kolejnego roku.

Ponieważ w badaniach nie uwzględniano firm z sektora finansów, dlatego roli portfela odniesienia nie mógł odgrywać indeks WIG. W rezultacie postanowiono zbudować portfel odniesienia, którym był dobrze zdywersyfikowany portfel proporcjonalny zawierający wszystkie spółki objęte badaniem w danym roku.

W celu oceny poszczególnych portfeli dla każdego z nich zostały wyznaczone:

- średnie tygodniowe logarytmiczne stopy zwrotu,

- odchylenie standardowe tygodniowych logarytmicznych stóp zwrotu,

- zrealizowana stopa zwrotu,

- wskaźnik Sharpe'a.

Wyznaczenie wskaźnika Sharpe'a wymaga znajomości wolnej od ryzyka stopy procentowej dla każdego z okresów. Jej wartość przyjęto na poziomie stopy WIBOR $12 \mathrm{M} \mathrm{z}$ dnia konstrukcji kolejnych portfeli.

\section{Wyniki badań}

W tabeli 2 zamieszczono zrealizowane stopy zwrotu dla portfeli budowanych na podstawie poszczególnych rankingów w latach 2001-2010. Porównanie stóp zwrotu uzyskanych z poszczególnych portfeli ze stopą zwrotu z portfela odniesienia wskazuje, że w przypadku rankingu TMAI_delta portfel 3 siedmiokrotnie przyniósł wyższą stopę zwrotu niż portfel odniesienia. Pozostałe portfele pozwoliły uzyskać wyższą stopę zwrotu niż portfel odniesienia od trzech do pięciu razy w ciągu dziesięciu lat. Natomiast w przypadku rankingu TMAI_nom_delta dwa portfele, tj. portfel 2 oraz portfel 4, przynajmniej siedmiokrotnie przyniosły wyższą stopę zwrotu niż portfel odniesienia. Pozostałe portfele w tym rankingu pozwoliły uzyskać wyższą stopę zwrotu niż portfel odniesienia od trzech do czterech razy w ciągu dziesięciu lat.

Analiza skumulowanych stóp zwrotu ze zbudowanych portfeli (zamieszczonych w tab. 3) wskazuje, że portfelami, które przyniosły wyższe skumulowane stopy zwrotu niż portfel odniesienia, były portfel 1 i portfel $3 \mathrm{w}$ przypadku rankingu TMAI delta oraz portfel 2 i portfel $4 \mathrm{w}$ przypadku rankingu TMAI_nom_delta. Przy czym skumulowana stopa zwrotu dla portfela $2 \mathrm{w}$ rankingu TMAI_nom_delta była blisko dwukrotnie wyższa niż dla portfela $4 \mathrm{w}$ rankingu TMAI_nom_delta, portfela $3 \mathrm{w}$ rankingu TMAI_delta oraz o ok. 50\% wyższa niż dla portfela $1 \mathrm{w}$ rankingu TMAI_delta. Bardzo dobry wynik portfela 2 rankingu TMAI_nom_delta jest rezultatem systematycznie lepszych wyników niż portfela odniesienia, co pokazano w tab. 2 .

Analiza średnich geometrycznych stóp zwrotu (ŚrGeo) ze zbudowanych portfeli (zamieszczonych w tab. 3) wskazuje, że portfelami, które przyniosły wyższe ŚrGeo niż portfel odniesienia, były portfel 2 i portfel 4 w rankingu TMAI_nom_delta oraz portfel 1 i portfel 3 w rankingu TMAI_delta. Przy czym ŚrGeo dla portfela 2 w rankingu TMAI_nom_delta była wyższa od ŚrGeo dla portfela odniesienia o 8,2 p.p. Drugi w kolejności pod względem ŚrGeo portfel 1 w rankingu TMAI_delta 
Weryfikacja zastosowania metody porządkowania liniowego Hellwiga...

Tabela 2. Zrealizowane stopy zwrotu z budowanych portfeli

\begin{tabular}{|c|c|c|c|c|c|c|c|c|c|c|c|}
\hline \multicolumn{2}{|c|}{ Rok } & 2001 & 2002 & 2003 & 2004 & 2005 & 2006 & 2007 & 2008 & 2009 & 2010 \\
\hline \multicolumn{2}{|r|}{$\begin{array}{c}\text { Portfel } \\
\text { odniesienia }\end{array}$} & $-12 \%$ & $-6 \%$ & $187 \%$ & $16 \%$ & $143 \%$ & $83 \%$ & $-28 \%$ & $-55 \%$ & $61 \%$ & $7 \%$ \\
\hline \multirow{5}{*}{$\begin{array}{l}\frac{\pi}{0} \\
\frac{\pi}{0} \\
\sum_{i}\end{array}$} & Portfel 1 & $-35 \%$ & $-29 \%$ & $188 \%$ & $8 \%$ & $420 \%$ & $88 \%$ & $-26 \%$ & $-59 \%$ & $58 \%$ & $34 \%$ \\
\hline & Portfel 2 & $-28 \%$ & $-10 \%$ & $195 \%$ & $-7 \%$ & $79 \%$ & $120 \%$ & $-25 \%$ & $-54 \%$ & $60 \%$ & $-3 \%$ \\
\hline & Portfel 3 & $-10 \%$ & $3 \%$ & $242 \%$ & $23 \%$ & $68 \%$ & $77 \%$ & $-18 \%$ & $-54 \%$ & $60 \%$ & $13 \%$ \\
\hline & Portfel 4 & $12 \%$ & $11 \%$ & $150 \%$ & $36 \%$ & $97 \%$ & $62 \%$ & $-37 \%$ & $-51 \%$ & $78 \%$ & $-8 \%$ \\
\hline & Portfel 5 & $1 \%$ & $-3 \%$ & $164 \%$ & $17 \%$ & $63 \%$ & $105 \%$ & $-34 \%$ & $-55 \%$ & $47 \%$ & $-2 \%$ \\
\hline \multirow{5}{*}{ 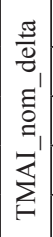 } & Portfel 1 & $-53 \%$ & $-46 \%$ & $188 \%$ & $12 \%$ & $372 \%$ & $80 \%$ & $-29 \%$ & $-63 \%$ & $49 \%$ & $29 \%$ \\
\hline & Portfel 2 & $-18 \%$ & $-17 \%$ & $251 \%$ & $35 \%$ & $150 \%$ & $122 \%$ & $-16 \%$ & $-53 \%$ & $74 \%$ & $8 \%$ \\
\hline & Portfel 3 & $-13 \%$ & $23 \%$ & $177 \%$ & $-1 \%$ & $103 \%$ & $72 \%$ & $-30 \%$ & $-49 \%$ & $63 \%$ & $2 \%$ \\
\hline & Portfel 4 & $7 \%$ & $17 \%$ & $201 \%$ & $16 \%$ & $66 \%$ & $105 \%$ & $-32 \%$ & $-55 \%$ & $71 \%$ & $-6 \%$ \\
\hline & Portfel 5 & $13 \%$ & $-5 \%$ & $121 \%$ & $16 \%$ & $38 \%$ & $67 \%$ & $-34 \%$ & $-54 \%$ & $47 \%$ & $1 \%$ \\
\hline
\end{tabular}

Pogrubioną czcionką zaznaczono zrealizowane stopy zwrotu, które w danym roku były wyższe niż stopa zwrotu z portfela odniesienia.

Źródło: opracowanie własne.

Tabela 3. Skumulowana stopa zwrotu i średnia geometryczna stopa zwrotu $\mathrm{z}$ budowanych portfeli

\begin{tabular}{|c|c|c|c|}
\hline \multicolumn{2}{|c|}{ Portfel odniesienia } & $\begin{array}{l}\text { Skumulowana } \\
\text { stopa zwrotu }\end{array}$ & $\begin{array}{c}\text { Średnia geometryczna } \\
\text { stopa zwrotu }\end{array}$ \\
\hline & & $583,0 \%$ & $21,2 \%$ \\
\hline \multirow{5}{*}{ 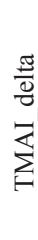 } & Portfel 1 & $797,2 \%$ & $24,5 \%$ \\
\hline & Portfel 2 & $279,6 \%$ & $14,3 \%$ \\
\hline & Portfel 3 & $686,0 \%$ & $22,9 \%$ \\
\hline & Portfel 4 & $581,0 \%$ & $21,1 \%$ \\
\hline & Portfel 5 & $328,5 \%$ & $15,7 \%$ \\
\hline \multirow{5}{*}{ 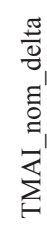 } & Portfel 1 & $252,9 \%$ & $13,4 \%$ \\
\hline & Portfel 2 & $1212,5 \%$ & $29,4 \%$ \\
\hline & Portfel 3 & $496,0 \%$ & $19,5 \%$ \\
\hline & Portfel 4 & $649,2 \%$ & $22,3 \%$ \\
\hline & Portfel 5 & $191,2 \%$ & $11,3 \%$ \\
\hline
\end{tabular}

Pogrubioną czcionką zaznaczono wartości wyższe niż dla portfela odniesienia.

Źródło: opracowanie własne.

miał ŚrGeo wyższą o 3,3 p.p. niż portfel odniesienia. Portfel $5 \mathrm{w}$ rankingu TMAI nom_delta pozwolił uzyskać najniższą ŚrGeo, tj. 11,3\%, która jest o 9,9 p.p. niższa od ŚrGeo dla portfela odniesienia. Różnica pomiędzy ŚrGeo dla portfela 2 i portfela $5 \mathrm{w}$ rankingu TMAI_nom_delta wyniosła 18,1 p.p. 
W tabeli 4 zamieszczono wartości ryzyka (mierzonego odchyleniem standardowym w skali roku) dla poszczególnych portfeli oraz średni poziom ryzyka w latach 2001-2010. Analiza wyników wskazuje, że:

- jeden portfel, tj. portfel 4, w rankingu TMAI_nom_delta miał średnie ryzyko niższe niż portfel odniesienia,

- najczęściej niższym ryzykiem niż portfel odniesienia, tj. pięciokrotnie niższym, charakteryzował się portfel $4 \mathrm{w}$ rankingu TMAI_nom_delta,

- portfel $1 \mathrm{w}$ obu rankingach w każdym roku charakteryzował się wyższym ryzykiem niż portfel odniesienia,

- portfel $2 \mathrm{w}$ rankingu TMAI_nom_delta jednokrotnie miał niższe ryzyko niż portfel odniesienia, a jego średnie ryzyko było o 5,2 p.p. wyższe niż ryzyko portfela odniesienia.

Tabela 4. Ryzyko budowanych portfeli oraz średni poziom ryzyka

\begin{tabular}{|c|c|c|c|c|c|c|c|c|c|c|c|c|}
\hline \multicolumn{2}{|c|}{ Rok } & 001 & 2002 & 003 & 2004 & 2005 & 2006 & 2007 & 2008 & 2009 & 2010 & $\begin{array}{l}\text { Średnie } \\
\text { ryzyko }\end{array}$ \\
\hline \multicolumn{2}{|c|}{$\begin{array}{c}\text { Portfel } \\
\text { odniesienia }\end{array}$} & $4 \%$ & $0^{\circ} \quad-$ & $22 \%$ & 1 & 2 & 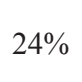 & 2 & $30^{\circ}$ & $70 \%$ & $\%$ & 66 \\
\hline \multirow{5}{*}{$\begin{array}{l}\frac{\pi}{0} \\
\frac{\pi}{0} \\
\mathbb{Z}\end{array}$} & 1 & $1 \%$ & $10 \%$ & $30 \%$ & $21 \%$ & 45 & $35 \%$ & $30 \%$ & $35 \%$ & $24 \%$ & $0 \%$ & $27,6 \%$ \\
\hline & - & $17 \%$ & $18 \%$ & $31 \%$ & 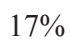 & 200 & $31 \%$ & $27 \%$ & $330 \%$ & $19 \%$ & $14 \%$ & $22,7 \%$ \\
\hline & Portfel 3 & $15 \%$ & $15 \%$ & $23^{\circ}$ & $21 \%$ & $16^{\circ}$ & $23 \%$ & $27^{\circ}$ & 32 & 220 & 160 & $21,1 \%$ \\
\hline & Portfel 4 & $4 \%$ & $2 \%$ & $21 \%$ & $21 \%$ & $20^{\circ}$ & $23 \%$ & $29 \%$ & $30 \%$ & $18 \%$ & $2 \%$ & $19,9 \%$ \\
\hline & & 140 & 120 & $25 \%$ & 160 & & 370 & 270 & & 150 & $11 \%$ & \\
\hline \multirow{2}{*}{$\frac{\pi}{\frac{\pi}{0}}$} & Portfel 1 & $0 \%$ & $17 \%$ & 30 & - & $52^{\circ}$ & $33 \%$ & 32 & - & $27 \%$ & 20 & $29,3 \%$ \\
\hline & Portfel 2 & $18 \%$ & $0 \%$ & 33 & 23 & & $32 \%$ & 3 & $30 \%$ & 70 & 6 & $24,8 \%$ \\
\hline \multirow{3}{*}{ 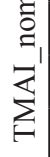 } & Portfel 3 & 1470 & 1570 & $24 \%$ & $15 \%$ & 210 & $25 \%$ & 20 & 5170 & 1070 & 1770 & $20,1 \% 0$ \\
\hline & Portfel 4 & $3 \%$ & $2 \%$ & $23^{\circ}$ & $17 \%$ & $14^{\circ}$ & $27 \%$ & $26 \%$ & $27 \%$ & $18 \%$ & $12 \%$ & $19,0 \%$ \\
\hline & Portfel 5 & $\%$ & $3 \%$ & $24 \%$ & $17 \%$ & $16 \%$ & $25 \%$ & $27 \%$ & $34 \%$ & $15 \%$ & $11 \%$ & $19,6 \%$ \\
\hline
\end{tabular}

Pogrubioną czcionką zaznaczono ryzyko, które w danym roku było niższe niż ryzyko portfela odniesienia.

Źródło: opracowanie własne.

W tabeli 5 zamieszczono wskaźniki Sharpe'a dla zbudowanych portfeli. Analiza wyników wskazuje, że:

- portfel odniesienia w sześciu na dziesięć analizowanych lat miał dodatnią wartość wskaźnika Sharpe'a, co oznacza, że tylko w tych latach przyniósł średnią stopę zwrotu wyższą niż stopa wolna od ryzyka,

- zbudowane portfele od 4 do 6 razy miały dodatnią wartość wskaźnika Sharpe'a,

- portfel $2 \mathrm{w}$ rankingu TMAI_nom_delta siedmiokrotnie miał wyższą wartość wskaźnika Sharpe'a niż portfel odniesienia, z czego trzykrotnie dotyczyło to 
dodatnich wartości tego wskaźnika. Jednocześnie portfel odniesienia trzykrotnie miał wyższą dodatnią wartość wskaźnika Sharpe'a. Ponadto portfel ten jest portfelem o najwyższej średniej geometrycznej stopie zwrotu,

- portfel $3 \mathrm{w}$ rankingu TMAI_delta siedmiokrotnie miał wyższą wartość wskaźnika Sharpe'a niż portfel odniesienia, z czego trzykrotnie dotyczyło to dodatnich wartości tego wskaźnika. Jednocześnie portfel odniesienia trzykrotnie miał wyższą dodatnią wartość wskaźnika Sharpe'a,

- portfel $1 \mathrm{w}$ rankingu TMAI_delta trzykrotnie miał wyższą wartość wskaźnika Sharpe'a niż portfel odniesienia, z czego jednokrotnie dotyczyło to dodatnich wartości tego wskaźnika. Jednocześnie portfel odniesienia pięciokrotnie miał wyższą dodatnią wartość wskaźnika Sharpe'a,

- portfel $4 \mathrm{w}$ rankingu TMAI_nom_delta (o najniższym średnim ryzyku) sześciokrotnie miał wyższą wartość wskaźnika Sharpe'a niż portfel odniesienia, z czego trzykrotnie dotyczyło to dodatnich wartości tego wskaźnika. Jednocześnie portfel odniesienia trzykrotnie miał wyższą dodatnią wartość wskaźnika Sharpe’a.

Tabela 5. Wskaźniki Sharpe'a budowanych portfeli

\begin{tabular}{|c|c|c|c|c|c|c|c|c|c|c|c|}
\hline \multicolumn{2}{|c|}{ Rok } & 2001 & 2002 & 2003 & 2004 & 2005 & 2006 & 2007 & 2008 & 2009 & 2010 \\
\hline \multicolumn{2}{|c|}{$\begin{array}{c}\text { Portfel } \\
\text { odniesienia }\end{array}$} & $-2,06$ & $-1,49$ & 4,54 & 0,55 & 3,53 & 2,33 & $-1,40$ & $-2,85$ & 2,48 & 0,17 \\
\hline \multirow{5}{*}{$\begin{array}{l}\frac{\pi}{0} \\
\frac{8}{0} \\
3\end{array}$} & Portfel 1 & $-3,35$ & $-2,82$ & 3,30 & 0,08 & 3,18 & 1,67 & $-1,16$ & $-2,84$ & 1,76 & 1,28 \\
\hline & Portfel 2 & $-2,86$ & $-1,11$ & 3,34 & $-0,74$ & 2,53 & 2,43 & $-1,24$ & $-2,52$ & 2,22 & $-0,54$ \\
\hline & Portfel 3 & $-1,66$ & $-0,45$ & 5,00 & 0,70 & 2,88 & 2,31 & $-0,90$ & $-2,65$ & 1,94 & 0,50 \\
\hline & Portfel 4 & $-0,26$ & 0,04 & 4,11 & 1,20 & 2,99 & 1,94 & $-1,74$ & $-2,64$ & 3,05 & $-1,03$ \\
\hline & Portfel 5 & 1,02 & $-0,96$ & 3 , & 0,63 & 4 & 1,80 & $-1,70$ & $-2,85$ & 34 & $-0,61$ \\
\hline \multirow{5}{*}{ 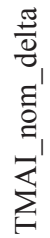 } & Portfel 1 & $-4,50$ & $-4,23$ & 3,33 & 0,20 & 2,84 & 1,67 & $-1,21$ & $-2,80$ & 1,32 & 1,07 \\
\hline & Portfel 2 & $-1,95$ & $-1,42$ & 3,60 & 1,03 & 3,61 & 2,32 & $-0,72$ & $-2,77$ & 2,46 & 0,22 \\
\hline & Portfel 3 & $-2,05$ & 0,75 & 4,09 & $-0,46$ & 3,02 & 2,17 & $-1,55$ & $-2,42$ & 2,52 & $-0,19$ \\
\hline & Portfel 4 & $-0,61$ & 0,50 & 4,53 & 0,52 & 3,07 & 2,48 & $-1,63$ & $-3,12$ & 2,84 & $-0,86$ \\
\hline & Portfel 5 & $-0,19$ & $-1,19$ & 3,05 & 0,56 & 1,63 & 1,89 & $-1,73$ & $-2,45$ & 2,23 & $-0,30$ \\
\hline
\end{tabular}

Pogrubioną czcionką zaznaczono wskaźnik Sharpe'a, który w danym roku był wyższy niż wskaźnik Sharpe'a dla portfela odniesienia.

Źródło: opracowanie własne.

Porównanie wartości wskaźnika Sharpe'a dla portfela 2 w rankingu TMAI nom_delta (o najwyższej ŚrGeo) oraz portfela 1 i portfela 3 w rankingu TMAI_delta (portfele o najwyższej ŚrGeo wśród portfeli w rankingu TMAI_delta) wskazuje, że: - portfel 2 co najmniej czterokrotnie miał wyższą dodatnią wartość wskaźnika Sharpe'a niż pozostałe portfele,

- portfel 1 oraz portfel 3 najwyżej dwukrotnie miały wyższą dodatnią wartość wskaźnika Sharpe’a niż portfel 2. 
Porównanie wartości wskaźnika Sharpe'a dla portfela 2 w rankingu TMAI_nom delta (o najwyższej ŚrGeo) oraz portfela $4 \mathrm{w}$ rankingu TMAI_nom_delta (o najniższym średnim ryzyku) wskazuje, że:

- portfel 2 trzykrotnie miał wyższą dodatnią wartość wskaźnika Sharpe'a niż portfel 4, - portfel 4 czterokrotnie miał wyższą dodatnią wartość wskaźnika Sharpe'a niż portfel 2 .

Uzyskane wartości wskaźników Sharpe’a pozwalają stwierdzić, że lepszymi portfelami są portfele zbudowane na podstawie rankingu TMAI_nom_delta niż portfele zbudowane na podstawie rankingu TMAI_delta. Natomiast nie pozwalają jednoznacznie stwierdzić, który z portfeli w rankingu TMAI_nom_delta (portfel 2 czy portfel 4) jest istotnie najlepszy pod względem wskaźnika Sharpe’a.

\section{Podsumowanie}

Celem pracy była próba odpowiedzi na pytanie, czy dobierając spółki do portfela, należy je oceniać, wykorzystując jednocześnie wartości nominalne wskaźników finansowych oraz ich względne tempa przyrostu, czy też do oceny spółek wystarczy wykorzystać względne tempa przyrostu wskaźników finansowych. W badaniach (w celu oceny przydatności obu grup zmiennych) konstruowano dwa rankingi: jeden na podstawie wartości nominalnych wskaźników finansowych oraz ich względnych temp przyrostu (TMAI_nom_delta), drugi na podstawie względnych temp przyrostu wskaźników finansowych (TMAI_delta). Na podstawie pozycji spółek w rankingach kwalifikowano je do portfeli kwantylowych.

Uzyskane wyniki pozwalają stwierdzić, że w kontekście doboru spółek do portfela powinno się je oceniać, wykorzystując wartości nominalne wskaźników finansowych oraz ich względne tempa przyrostu. Wykorzystanie jedynie względnych temp przyrostu wskaźników finansowych prowadzi do budowy portfeli kwantylowych o niższych średnich geometrycznych stopach zwrotu oraz o niższych wartościach wskaźnika Sharpe'a, niż ma to miejsce w przypadku, gdy do budowy portfeli kwantylowych wykorzystuje się zarówno wartości nominalne wskaźników finansowych, jak i ich względne tempa przyrostu.

\section{Literatura}

Bednarski L., Waśniewski T. (red.), Analiza finansowa $w$ zarządzaniu przedsiębiorstwem, Wyd. FRR, Warszawa 1996, Tom I.

Helfert E.A., Techniki analizy finansowej, PWE, Warszawa 2003.

Hellwig Z., Zastosowanie metody taksonomicznej do typologicznego podziatu krajów ze względu na poziom ich rozwoju i strukture wykwalifikowanych kadr, „Przegląd Statystyczny” 1968, nr 4, s. 307-324.

Jerzemowska M. (red.), Analiza ekonomiczna w przedsiębiorstwie, PWE, Warszawa 2006.

Łuniewska M., Porównanie parametrów portfeli zbudowanych przy wykorzystaniu wybranych metod WAP z portfelem rynkowym, „Prace Naukowe” nr 991, AE, Wrocław 2003 a. 
Łuniewska M., Wykorzystanie metod ilościowych do tworzenia portfela papierów wartościowych, Wyd. Uniwersytetu Szczecińskiego, Rozprawy i Studia, tom 484, Szczecin $2003 \mathrm{~b}$.

Markowitz H., Portfolio selection, "The Journal of Finance" 1952, nr 7(1).

Ritchie J.C., Analiza fundamentalna, WIG-Press, Warszawa 1997.

Sharpe W.F., Mutual fund performance, “Journal of Business”, January 1966, vol. 39, Issue 1, s. 119.

Tarczyński, W., Taksonomiczna miara atrakcyjności inwestycji w papiery wartościowe, „Przegląd Statystyczny" 1994, nr 3, s. 275-300.

Tarczyński W., Łuniewska M., Dywersyfikacja ryzyka a fundamentalny portfel papierów wartościowych, "Prace Naukowe" nr 991, AE, Wrocław 2003.

Tarczyński W., Łuniewska M., Dywersyfikacja ryzyka na polskim rynku kapitałowym, Placet, Warszawa 2004.

Waśniewski T., Skoczylas W., Analiza przepływów środków pieniężnych - pomoca $w$ zarządzaniu finansami przedsiębiorstwa, „, Rachunkowość” 1996, nr 6.

Waśniewski T., Skoczylas W., Jak korzystać ze sprawozdania z przepływu środków pieniężnych, , Rachunkowość" 1999, nr 12.

Waśniewski T., Skoczylas W., Teoria i praktyka analizy finansowej w przedsiębiorstwie, Wyd. FRR, Warszawa 2002.

Wędzki D., Analiza wskaźnikowa sprawozdania finansowego, O.W. Wolters Kluwer Polska, Kraków 2006.

Węgrzyn T., TMAI - porównanie dwóch metod wyznaczania tempa przyrostu dla ujemnych wartości wskaźników finansowych, [w:] Zeszyty Naukowe Uniwersytetu Szczecińskiego nr 462, Uniwersytet Szczeciński, Szczecin 2007.

Węgrzyn T., Dobór spótek do portfela z wykorzystaniem wskaźników finansowych i ich względnego tempa przyrostu. Analiza w latach 2001-2010, [w:] J. Harasim, B. Frączek (red.), Studia ekonomiczne. Innowacje $w$ bankowości i finansach, Zeszyty Naukowe Wydziałowe, Katowice 2013a, nr 174, s. 63-74.

Węgrzyn T., Stock Selection Based on Financial Ratios on the Warsaw Stock Exchange. Analysis between 2001 and 2010, [w:] European Financial Systems 2013. Proceedings of the 10th International Scientific Conference, Masaryk University, Brno 2013b, s. 356-361.

Węgrzyn T., Stock Selection on the Warsaw Stock Exchange Financial Ratios or Profitability Ratios. Analysis between 2001 and 2011, [w:] T. Löster, T. Pavelka (red.), The 7th International Days of Statistics and Economics, Conference Proceedings, Libuše Macáková, MELANDRIUM, Prague 2013c, http://msed.vse.cz/msed_2013, s. 1554-1564.

\section{VERIFICATION OF THE APPLICATION OF THE HELLWIG LINEAR ARRANGEMENT METHOD IN THE CONTEXT OF STOCK SELECTION. ANALYSIS BETWEEN 2001 AND 2010}

Summary: The purpose of the article is to check if companies should be assessed on the base of dynamics of the financial ratios or both dynamics of financial ratios and nominal values of financial ratios. In order to point out the better portfolio their performances are compared. Companies are chosen to quantile portfolios due to their position in the ranking that is constructed on the base of the chosen financial ratios (nominal values and/or their dynamics). As a result, it can be stated that the best portfolios are two portfolios pointed out by the ranking constructed on the base of nominal value of financial ratios and their dynamics.

Keywords: financial ratios, portfolio construction, synthetic measure of development. 